\title{
RANCANG BANGUN ALAT CUCI TANGAN OTOMATIS PORTABLE DENGAN TEKNOLOGI MIKROKONTROLER ARDUINO UNO
}

\section{DESIGN OF PORTABLE AUTOMATIC HAND WASHER WITH ARDUINO UNO MICROCONTROLLER TECHNOLOGY}

\author{
Rizki Febriansyach ${ }^{1}$, Dian Budhi Santoso ${ }^{2}$, Ulinnuha Latifa ${ }^{3}$ \\ 1,2,3 Universitas Singaperbangsa Karawang \\ 1rizki.febriansyach16126@student.unsika.ac.id, ${ }^{2}$ dian.budhi@ft.unsika.ac.id, \\ 3ulin.ft.unsika@gmail.com
}

\begin{abstract}
Abstrak
Mencuci tangan merupakan suatu kegiatan yang sangat penting bagi Kesehatan. Berdasarkan data Riskesdas 2018 sebanya 49,8\% dari jumlah populasi di Indonesia masih belum menerapkan pola hidup bersih. Berdasarkan hal tersebut maka diperlukan suatu media yang dapat menarik minat masyarakat untuk menerapkan pola hidup bersih. Sehingga dibuatlah sebuah alat cuci tangan otomatis portable dengan menggunakan teknologi Arduino sebagai mikrokontroler kendali dan monitoring. Alat cuci tangan ini menggunkana panel surya dengan kapasitas $10 \mathrm{Wp}$ dan baterai $12 \mathrm{~V} / 5 \mathrm{Ah}$, dimana berdasarkan hasil pengujian yang dilakukan menyatakan bahwa panel surya dan baterai yang digunakan tidak optimal untuk dapat menjalankan sistem alat cuci tangan otomatis tersebut.
\end{abstract}

\section{Kata kunci : Mikrokontroler, Arduino, Panel surya, Baterai}

\section{Abstract}

Washing hands is an activity that is very important for health. Based on the 2018 Riskesdas data, $49.8 \%$ of the total population in Indonesia still has not implemented a clean lifestyle. Based on this, we need a media that can attract public interest in implementing a clean lifestyle. So that a portable automatic handwashing tool was made using Arduino technology as a microcontroller control and monitoring. This handwashing tool uses a solar panel with a capacity of $10 \mathrm{Wp}$ and a $12 \mathrm{~V} / 5 \mathrm{Ah}$ battery, which is based on the results of tests that state that the solar panel and battery used are not optimal to be able to run the automatic handwashing system.

\section{Keywords: Microcontroller, Arduino, Solar cell, Battery}

\section{PENDAHULUAN}

Indonesia merupakan negara kepulauan dengan jumlah penduduk terbanyak nomor 4 (empat) di dunia. Menurut Pew Research Center (2019), Indonesia menjadi urutan ke-4 jumlah populasi terbanyak di dunia dengan jumlah populasi sebanyak 274 juta jiwa. Dengan jumlah penduduk yang banyak tidak menutup kemungkinan masyarakat Indonesia rentan terkena berbagai penyakit karena gaya hidup yang kurang baik, khususnya kebiasaan untuk selalu mencuci tangan [1].

Berdasarkan data Riskesdas tahun 2018, kebiasaan perilaku mencuci tangan yang baik dan benar masyarakat Indonesia menunjukan angka 49,8\% dari jumlah populasi di Indonesia [2]. Data tersebut menunjukan mayoritas masyarakat di Indonesia masih kurang dalam pengetahuan terkait 
cara cuci tangan yang baik dan benar sesuai anjuran World Health Organization (WHO). Era new normal di tahun 2020 menuntut masyarakat dunia untuk membiasakan diri selalu mencuci tangan saat akan melakukan kegiatan ataupun setelah melakukan kegiatan. Sehingga diperlukannya edukasi secara menyeluruh dengan media yang lebih menarik dan modern dalam era digitalisasi seperti saat ini.

Pada penelitian terdahulu yang dilakukan Henry pada tahun 2018 menceritakan alat serupa dengan menggunakan sensor infrared sebagai input untuk menghidupkan pompa [3]. Penelitian yang dilakukan Himsar Ambarita dan Halim Nasution pada tahun 2018 menjelaskan tentang teknologi pengisian baterai menggunakan panel surya [4]. Pada penelitian Kristyawati dan Nurcahyo pada tahun 2017 menjelaskan tentang perancangan alat pencuci dan pengering tangan otomatis menggunakan mikrokontroler Atmega16 dan scrolling text message display [5]. Pada penelitian yang akan dilakukan ini akan menggabungkan ketiga penelitian yang sudah dilakukan, hanya saja tidak menggunakan pengering tangan dan Atmega16.

Berdasarkan permasalahan tersebut, muncul sebuah solusi untuk membuat suatu alat yang dapat memberikan edukasi kepada masyarakat terkait mencuci tangan yang baik dan benar. Solusi tersebut yaitu membuat alat cuci tangan otomatis dan portable, sehingga dapat diletakan di areaarea yang menurut data Riskesdas masih minim edukasi terkait cuci tangan.

Berdasarkan latar belakang diatas, maka rumusan masalah pada penelitian adalah pertama, ingin mengetahui bagaimana perancangan alat cuci tangan otomatis portable. Kedua, ingin mengetahui bagaimana cara kerja alat cuci tangan otomatis portable. Ketiga, ingin mengetahui hasil dari pengujian alat cuci tangan otomatis portable.

\section{DASAR TEORI/MATERIAL DAN METODOLOGI/PERANCANGAN}

\subsection{Pentingnya Mencuci Tangan}

Mencuci tangan merupakan suatu hal yang diharuskan ditengah pandemic Covid-19, World Health Organization (WHO) menganjurkan masyarakat untuk selalu menerapkan pola hidup bersih dan sehat. Selain itu, World Health Organization (WHO) menyatakan bahwa kedua tangan merupakan jalur utama masuknya kuman penyakit ke dalam tubuh. Angka kejadian berbagai penyakit infeksi di Indonesia, seperti diare, tifus, dan disentri juga cukup tinggi [6]. Media untuk menyadarkan masyarakat agar selalu dapat menarik minat masyarakat tentu saja haruslah menarik. Penggunaan teknologi mikrokontroler Arduino untuk sistem kontrol yang dapat mengatur wakt kerja pompa alat cuci tangan otomatis [7].

\subsection{Metode, Alat dan Bahan}

Metode eksperimen dilakukan dengan perancangan alat cuci tangan otomatis portable dengan menggunakan teknologi Arduino sebagai sistem kendalinya. Data yang akan diambil juga diperoleh melalui metode eksperimen. Alat yang akan dibuat diharapkan dapat berguna untuk masyarakat agar lebih tertarik untuk menerap pola hidup bersih dan sehat. Dalam proses pembuatan alat ini :mengguanakan beberapa alat dan bahan, yaitu;

1. Perangkat Keras (Hardware)

Perangakt keras adlaah sebuah komponen fisik yang digunakan untuk menjalankan perintah yang telah di program. Perangkat keras adalah komponen fisik yang dapat dilihat, terdiri dari perangakt input dan output, yang dapat digunakan untuk menjalankan sistem yang telah dirancang.

2. Perangkat Lunak (Software) 
Perangkat lunak adalah program yang berisi perintah-perintah untuk menjalankan sistem yang telah dirancang. Perangkat lunak sering disebut sebagai program computer yang memuat perintah-perintah yang dibutuhkan oleh perangkat keras untuk melengkapi tugastugas yang diperlukan.

\subsection{Perangkat Keras dan Lunak}

Berikut ini adalah beberapa perangkat keras yang digunakan untuk perancangan sistem pada penelitian ini, diantaranya:

1. Mikrokontroler Arduino, sebagai pengolah perintah dari sensor yang digunakan untuk kendali.

2. Sensor Infrared, digunakan sebagai inputan untuk menjalankan sistem alat.

3. Pompa DC, digunakan sebagai output.

4. Relay, digunakan untuk mengatur pompa sesuai dengan perintah yang telah deprogram.

5. Baterai, sebagai power supply.

6. Panel Surya, digunakan untuk menghasilkan daya untuk charging baterai.

7. Solar Charger Controller, digunakan untuk mengatur arus dan tegangan yang masuk ke baterai dari panel surya.

Berikut ini adalah beberapa perangkat lunak yang digunakan untuk perancangan sistem pada penelitan ini, diantaranya:

1. Arduino Software (Intergrated Developmnet Environment), sebagai text editor untuk membuat, mengedit, dan juga mevalidasi syntax program yang dibuat.

2. Invetor Autocad 2017, digunakan untuk merancang desain alat.

\subsection{Flowchart Penelitian}

Penilitan merupakan kegiatan sistematis dengan serangkaian proses yang dilakukan secara terstruktur. Setiap tahapan proses akan selain berhubungan, dimana suatu proses yang dilakukan merupakan bagian dari tahapan yang menentukan proses selanjutnya. Maka dari itu perlu adanya metodologi penelitian sebagai langkah untuk melakukan tahapan-tahapan secara teliti dan sistematis. Tahapan proses tersebut digambarkan dalam flowchart metodologi penelitian seperti pada gambar 1 . 


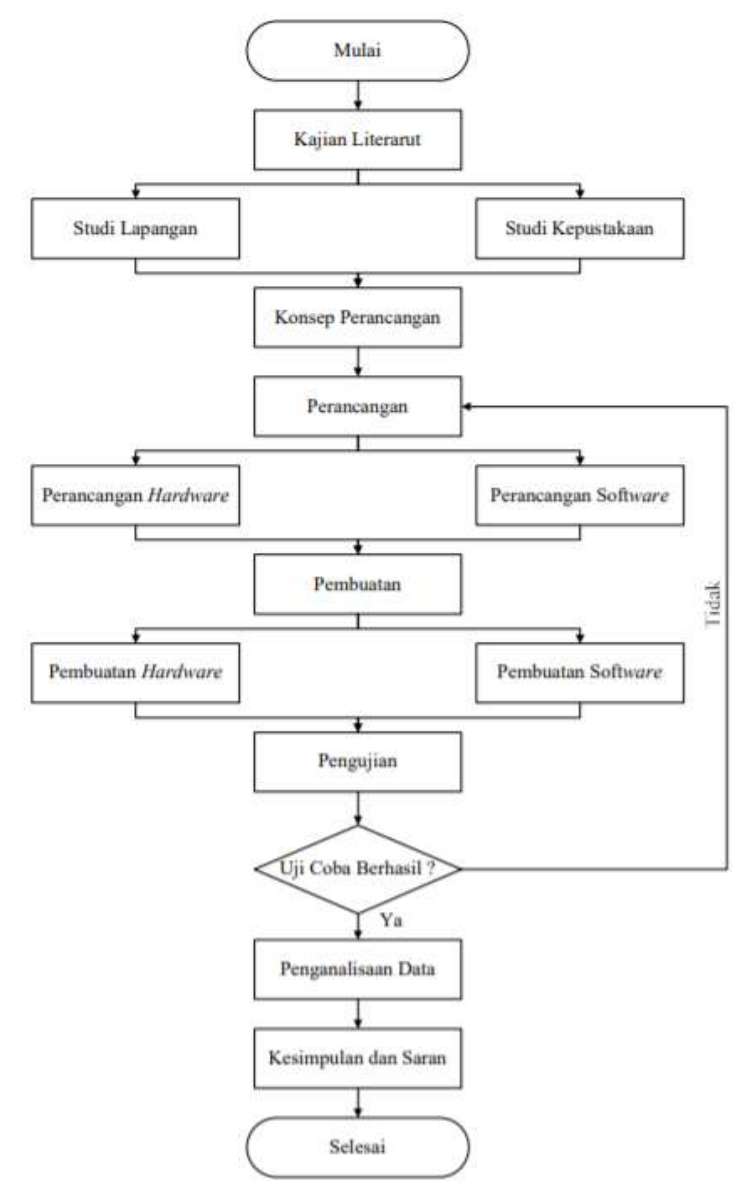

Gambar 1. Flowchart Penelitian

\section{HASIL DAN PEMBAHASAN}

Pembahasan pada penelitian dibagi menjadi beberapa pembahasan terkait hasil pengujian dan perancangan sistem alat.

\subsection{Flowchart Sistem Pengisian Baterai}

Pada bagian ini akan menjelaskan mengenai flowchart pada sistem pengisian baterai menggunakan panel surya. 


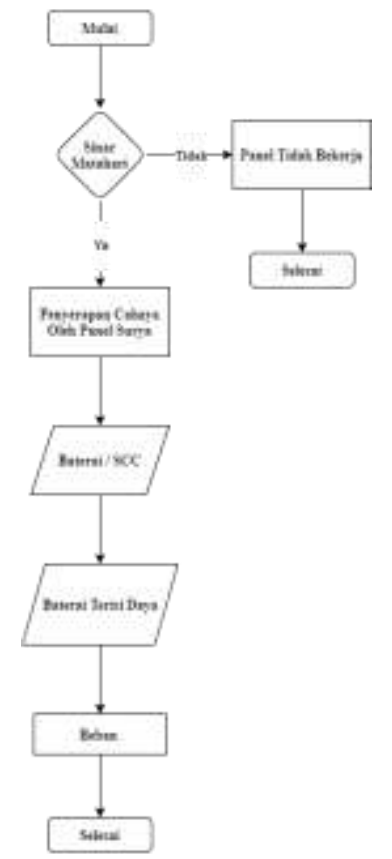

Gambar 2. Flowchart Sistem Pengisian Baterai

Gambar 2 memperlihatkan alur kerja pada sistem pengisian baterai yang digunakan, dimana pengisian baterai dilakukan dengan menggunakan panel surya berkapasitas $10 \mathrm{Wp}$. Baterai yang digunakan memiliki kapasitas sebesar $12 \mathrm{~V} / 5 \mathrm{Ah}$.

\subsection{Rangkaian Elektronika}

Bagian ini akan menjabarkan mengenai rangkaian elektronika sistem alat yang sudah dirancang, dengan menggunakan beberapa komponen.

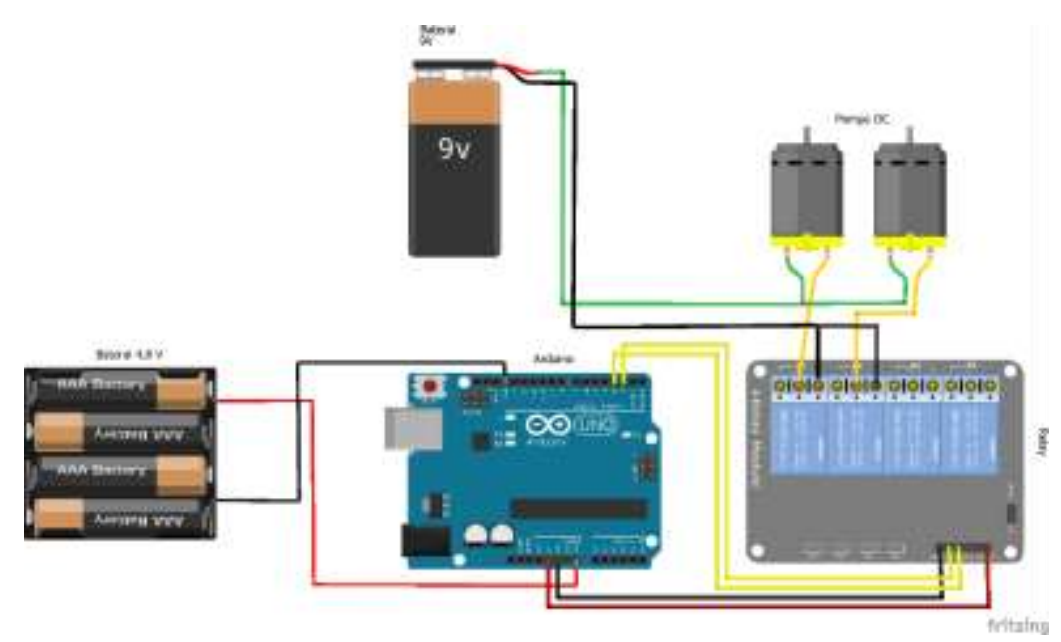

Gambar 3. Rangkaian Elektronika Alat

Gambar 3 menjelaskan mengenai sistem kerja alat, dimana Arduino berfungsi untuk menjalankan program yang sudah dibuat untuk menghidupkan pompa sesuai dengan perintah yang telah diprogram pada Arduino. 


\subsection{Perhitungan Beban Yang Digunakan}

Tabel 1. Beban yang digunakan

\begin{tabular}{|c|l|c|c|c|c|c|}
\hline No & Peralatan & Jumlah & $\begin{array}{c}\text { Daya } \\
\text { (Watt) } \\
(\text { VxI })\end{array}$ & $\begin{array}{c}\text { Durasi/Hari } \\
(\text { Jam })\end{array}$ & $\begin{array}{c}\text { Konsumsi } \\
\text { daya (Wh) }\end{array}$ \\
\hline 1 & Arduino & 1 & 0,2 & 24 & & 4,8 \\
\hline 2 & Relay Module & 1 & 0,15 & 5 & & 0,75 \\
\hline 3 & Pompa & 2 & 3 & 5 & & 30 \\
\hline 4 & Ultrasonik & 2 & 0,075 & 24 & & 3,6 \\
\hline 5 & Infrared & 1 & 0,125 & 5 & & 1,25 \\
\hline 6 & LCD & 1 & 0,009 & 24 & & 0,216 \\
\hline
\end{tabular}

Tabel 1 menjelaskan mengenai beban yang digunakan alat cuci tangan otomatis, dimana total daya yang dihasilkan sebesar 40,616 Wh. Sehingga perhitungan baterai dan panel yang digunakan seperti penjelasan sebagai berikut.

- Jumlah panel surya dibutuhkan

$10 \mathrm{Wp}$ x 5 jam terik matahari $=50 \mathrm{Wh} / \mathrm{hari}$

$50 \mathrm{Wh}-40,616=9,384 \mathrm{Wh} /$ hari (sisa)

- Baterai yang diperlukan (12 V/5 Ah)

$40,616:(12 \mathrm{~V} \times 5 \mathrm{Ah})$

$40,616: 60=0,676=1$ baterai

\subsection{Pengujian Panel Surya}

Pengujian sistem ini dilakukan untuk mengetahui daya yang dihasilkan panel surya apakah sudah optimal belum untuk melakukan pengisian baterai. Terdapat beberapa Langkah untuk melakukan pengujian ini.

1. Sambungkan kutub positif (+) baterai dengan port positif (+) baterai yang terdapat di SCC.

2. Sambungkan kutub negative (-) baterai dengan port negative (-) baterai yang terdapat di SCC.

3. Sambungkan keluaran positif (+) panel surya ke port positif pada SCC

4. Sambungkan keluaran negative (-) panel surya ke port negative pada SCC

5. Atur titik kordinat pengujian dengan menggunakan kompas.

6. Atur posisi panel surya untuk menghadap ke Barat dan Timur menyesuaikan dengan kompas. 
Tabel 2. Hasil Pengujian Panel Surya

\begin{tabular}{|c|c|c|c|c|}
\hline No & $\begin{array}{c}\text { Waktu } \\
(\text { Jam })\end{array}$ & $\begin{array}{c}\text { Tegangan } \\
(\mathrm{V})\end{array}$ & $\begin{array}{c}\text { Arus } \\
(\mathrm{A})\end{array}$ & $\begin{array}{c}\text { Daya } \\
(\text { Watt }) \\
(\mathrm{VxI})\end{array}$ \\
\hline 1 & 9.00 & 20.1 & 0.22 & 4.422 \\
\hline 2 & 10.00 & 19.6 & 0.41 & 8.232 \\
\hline 3 & 11.00 & 19.8 & 0.42 & 8.316 \\
\hline 4 & 12.00 & 19.1 & 0.32 & 6.112 \\
\hline 5 & 13.00 & 19.7 & 0.35 & 6.895 \\
\hline 6 & 14.00 & 20.1 & 0.31 & 6.231 \\
\hline 7 & 15.00 & 19.8 & 0.31 & 6.138 \\
\hline \multicolumn{5}{|c|}{ TOTAL } \\
\hline
\end{tabular}

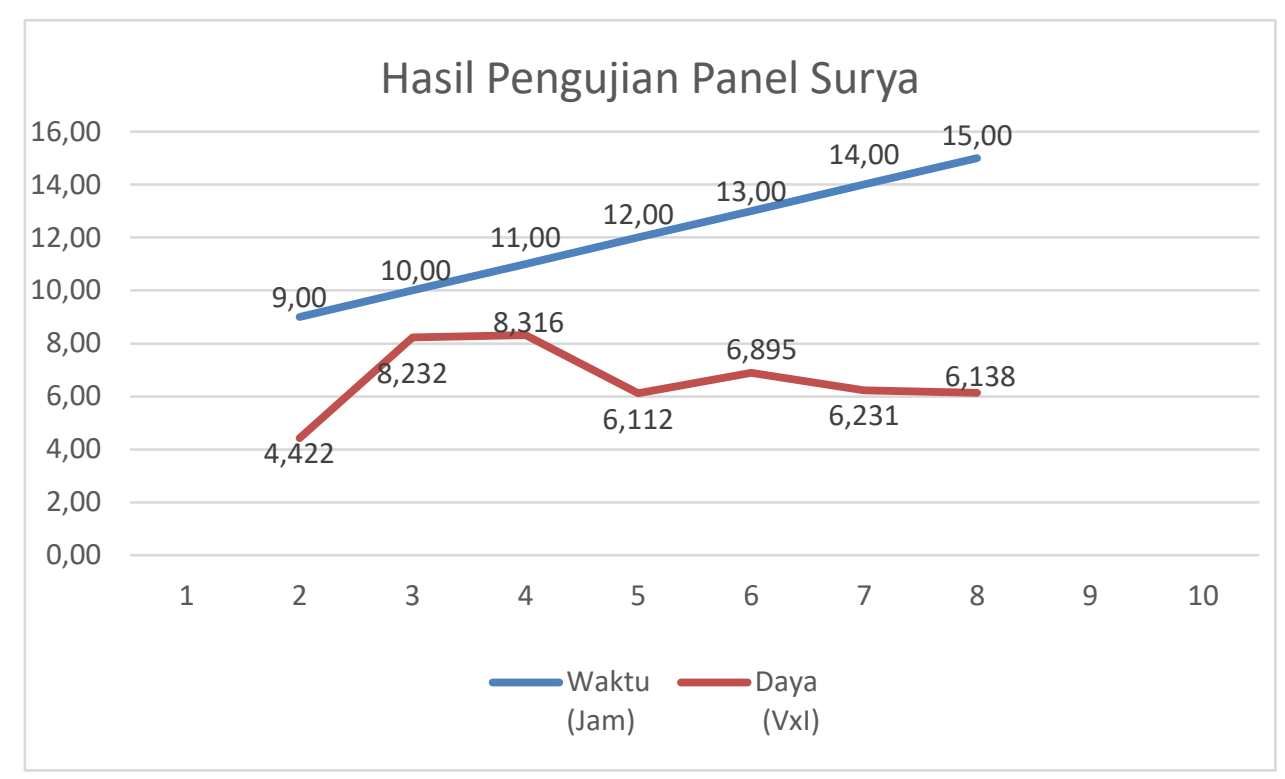

Gambar 4. Grafik Pengujian Panel Surya

Data hasil pengujian pada tabel 4.1 menunjukan pengambilan data nilai tengangan dan arus yang dilakukan sebanyak 7 kali menunjukan daya tertinggi terdapat pada pukul 11.00 WIB sebesar 8,232 Watt dan yang terkecil pada pukul 09.00 WIB sebesar 4,422 Watt. Hasil keseluruhan dari pengujian mendapatak nilai daya sebesar 46,346 Watt. Nilai rata-rata daya yang dihasilkan tiap jam sebesar 6,62 Watt, artinya dalam pengujian ini mendapatkan hasil yang kurang maksimal untuk melakukan pengisian baterai yang digunakan secara optimal. Nilai daya yang dihasilkan untuk digunakan pada beban yang digunakan sudah memenuhi perhitungan.

\subsection{Perhitungan Ketahanan Baterai}


Perhitungan ini bertujuan untuk mengetahui berapa lama baterai dapat digunakan berdasarkan beban yang digunakan. Beban yang digunakan sebesar 40,616 Watt dan baterai yang digunakan sebanyak 1 baterai dengan memiliki spesifikasi 12 V / 5 Ah. Perhitungan yang digunakan menggunakan rumus sebagai berikut:

Diketahui kapasitas beban $=40,616$ Watt

$$
\begin{gathered}
I=\frac{P}{V} \\
I=\frac{40,616}{12} \\
I=3,38 \mathrm{~A}
\end{gathered}
$$

Maka,

Waktu pemakaian $=5 \mathrm{Ah} / 3,38 \mathrm{~A}=1,48-$ diefesiensi baterai sebesar $20 \%$

$$
\text { Waktu pemakaian = 1,2 } \mathrm{Jam} \text { (70 menit) }
$$

Baterai dapat digunakan selama 70 menit dengan beban sebesar 40,616 Watt. Lama penggunaan baterai tergantung dengan berapa besar beban yang digunakan.

\subsection{Perhitungan Pengisian Baterai}

Perhitungan ini bertujuan untuk mengetahui daya yang dibutuhkan untuk dapat mengisi baterai secara optimal sesuai dengan spesifikasi baterai yang digunakan. Pengujian ini juga untuk mengetahui apakah daya yang dihasilkan panel surya sudah sesuai dengan daya yang dibutuhkan untuk melakukan pengisian baterai. Diketahui waktu pengisian baterai yang dilakukan selama 7 jam. Tegangan standart pengisian baterai adalah 13,8 Volt Baterai yang digunakan $12 \mathrm{~V} / 5 \mathrm{Ah}$, maka:

$$
I=5 \mathrm{Ah} / 7 \mathrm{jam}=0,7 \mathrm{~A}
$$

Tambahkan 20\% untuk diefisiensi baterai, maka kuat arus yang dibutuhkan untuk pengisian selama 7 jam adalah:

$$
I=0,7 A+20 \%=0,84 A
$$

Maka,

$$
\begin{gathered}
P=V \times I \\
P=13,8 \times 0,84 \\
P=11,59 \mathrm{Watt}
\end{gathered}
$$


Jadi, daya yang dibutuhkan untuk pengisian baterai $12 \mathrm{~V} / 5$ Ah sebesar 11,59 Watt.

\section{KESIMPULAN}

Berdasarkan hasil perhitungan dan pengujian yang telah dilakukan, mendapatkan bebrapa kesimpulan yang didapatkan, diantaranya:

1. Sistem perancangan cuci tangan otomatis portable ini berhasil berfungsi sesuai dengan yang di inginkan.

2. Panel surya dapat menghasilkan daya sebesar 46,364 Wh dengan rentang waktu penggunaan selama 7 jam. Hasil yang didapatkan dinyatakan kurang optimal dikarenakan membutuhkan waktu yang cukup lama.

3. Berdasarkan hasil perhitungan daya yang dibutuhkan untuk pengisian baterai diadapatkan hasil sebesar 11,59 Wh. Panel surya yang digunakan belum mencapai hasil tersebut sehingga pengisian yang dilakukan kurang optimal.

4. Perhitungan ketahanan baterai yang dilakukan mendapatkan hasil bahwa baterai hanya dapat bertahan selama 70 menit. Hal ini menyatakan bahwa baterai yang digunakan kurang optimal untuk menunjang penggunaan alat untuk digunakan lebih lama ketika panel surya tidak mendapatkan cahaya matahari.

\section{DAFTAR PUSTAKA}

[1.] D. H. Jayani, "databoks," 2020. [Online]. Available: https://databoks.katadata.co.id/datapublish/2019/12/16/2020-penduduk-indonesiaterbesar-keempat-dunia. [Accessed Selasa Juli 2020].

[2.] Kemenkes, Infodatin (Pusat Data dan Informasi Kementrian Kesehatan RI), 2018.

[3.] H. Hendri, "Pembersih Tangan Otomatis Dilengkapi Air, Sabun, Handdryer Dan Lcd Menggunakan Sensor Infrared Berbasis Arduino," vol. 8(1), pp. 1-14, 2018.

[4.] H. Ambarita dan H. Nasution, "teknologi pengisi baterai menggunakan surya," jurnal aplikasi dan inovasi iptek, vol. 1 no. 2, pp. 53-58, 2018.

[5.] D. Kristyawati dan I Nurcahyo, "PERANCANGAN ALAT PENCUCI DAN PENGERING TANGAN OTOMATIS MENGGUNAKAN MIKROKONTROLLER ATMEGA16 DAN SCROLLING TEXT MESSAGE DISPLA. JURNAL TEKNIK FTUP, 28, 12.," jurnal teknik FTUP, pp. 28,12.

[6.] L. Budiarso, "Pengaruh Cuci Tangan Dalam Penurunan Jumlah Mikroba di Kulit Tangan," EBERS PAPYRUS, vol. 18 no. 1, 2012.

[7.] B. Y. Husodo dan R. Effendi, "Perancangan Sistem Kontrol dan Pengamanan Motor Pompa Air Terhadap Gangguan Tegangan dan Arus Berbasis Arduino," Jurnal Teknologi Elektro, Universitas Mercu Buana, vol. 4 no. 2, 2013 